\title{
The functional significance of the spinose keel structure of benthic foraminifera: inferences from Miliolina cristata Millett, 1898 (Miliolida) from northeast Romania
}

\author{
Simina Dumitriţa Dumitriu ${ }^{1}$, Zofia Dubicka ${ }^{2}$, and Viorel Ionesi ${ }^{1}$ \\ ${ }^{1}$ Alexandru Ioan Cuza University of Iasi, Department of Geology, Carol I Blvd., 20A, 700505, Iaşi, Romania \\ ${ }^{2}$ University of Warsaw, Faculty of Geology, Al. Żwirki i Wigury 93, 02-089, Warsaw, Poland
}

Correspondence: Simina Dumitriţa Dumitriu (siminadumitriu@gmail.com)

Published: 11 January 2018

\begin{abstract}
The paper presents Miocene (lower Sarmatian) benthic foraminifera from the $\mathrm{FH}_{3} \mathrm{P}_{1}$ Rădăuţi Core section from the northwestern part of the Moldavian Platform, Romania. Based on foraminiferal assemblages we infer sediments were deposited in shallow-water, including marine-marginal environments, of varying salinities from brackish to normal marine with some short and rather small sea-level changes. Moreover, we describe for the first time in the Moldavian Platform a very rare species, Miliolina cristata Millett, which presents a characteristic spinose keel. Based on a detailed study of the test morphology and its variability, observed in picked material as well as in thin sections, we discuss some palaeoecological aspects of these foraminifera. M. cristata probably does not constitute a distinctive species, but it is more probable that some miliolid taxa developed such an exoskeletal feature in response to new environmental conditions, such as more turbulent water. Accordingly, our study would support the thesis that one of the functions of the benthic foraminiferal spines is to stabilize foraminiferal tests found in sandy substrates from high-energy environments.
\end{abstract}

\section{Introduction}

The systematics of foraminifera, apart from the recently and thoroughly studied molecular data (e.g. Pawlowski et al., 2013), are mostly based on the test morphology (Loeblich and Tappan, 1984, 1987), including the number and shape of the chambers, the chamber arrangement, the shape and position of the aperture, and also the type of ornamentation (Haynes, 1981), which sometimes make the species identification very difficult. The high variability of species may result from the alternation of generations, from the ontogenetic development, or from the variation in environmental conditions, including even seasonal morphological variations (Pawlowski et al., 1994).

A lot of studies deal with the relationship between the morphological variation and environmental parameters such as salinity, temperature, depth, substrate, water motion and even pollution (e.g. Murray, 1963, 1973; Brasier, 1982; Corliss and Fois, 1990; Boltovskoy et al., 1991; Yanko et al., 1994, 1998; Polovodova and Schönfeld, 2008; Buosi et al., 2010;
Mellis and Covelli, 2013; Iglikowska and Pawlowska, 2015). Recent studies based on molecular data show significant variability within distinct molecular groups of foraminifera (Pawlowski and Holzman, 2002; Pawlowski et al., 2003; Longet and Pawlowski, 2007) and prove that two different morphotypes can correspond to the same species in spite of their morphological differences (Pillet et al., 2012, 2013). It is widely known that foraminiferal test morphotypes and their microhabitat are linked, which is commonly used as a proxy for palaeoenvironmental studies (e.g. Poag, 1982; Corliss, 1985; Jones and Charnock, 1985; Langer et al., 1989; Linke, 1992; Langer, 1993). It is also believed that benthic foraminifera utilize a variety of skeletal traits to help them adapt to the microhabitat they occupy (e.g. Altenbach et al., 1993; Murray, 1994; Dubicka et al., 2015), such as ornamentation, pseudo-spines, spikes, pustules, ribs, tubes or reticulate surface, which have specific functions, mostly mechanical (Hottinger, 2000). However, the function of many of them is still far from being understood. 


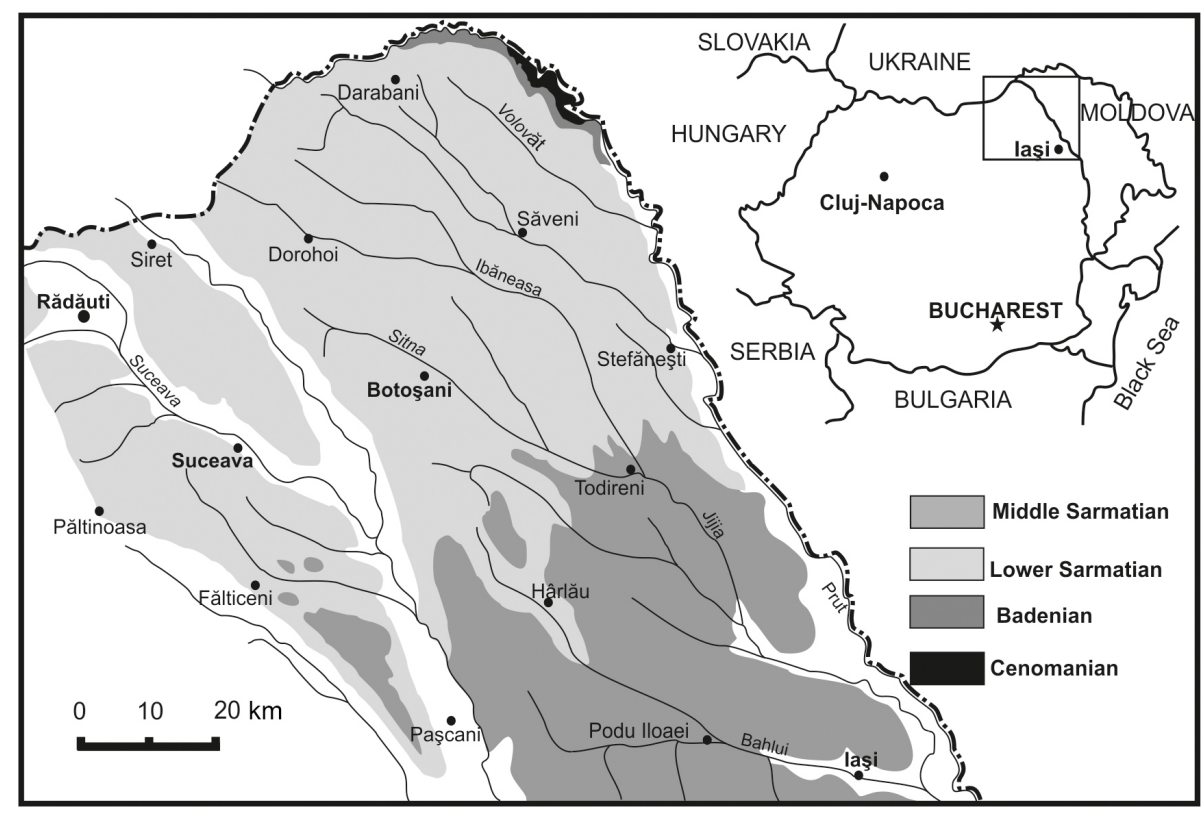

Figure 1. Geological map of the studied area (modified after Ionesi, 1994).

The spinose keel role, especially in relation to miliolid taxa, is very poorly understood. This test feature is more often observed in Elphidiidae (Elphidium reginum and $\mathrm{El}$ phidium aculeatum) and is very rare within miliolids. It has only been recorded in a few recent as well as fossil miliolid taxa (e.g. Miliolina cristata, Miliolina excisa, Miliolina calcarata, Pyrgo denticulina, Pyrgo serrata).

This paper first discusses the general function of spines, including the spinose keel, in benthic foraminifera. Moreover, we present the highly variable assemblage of Miliolina cristata, a miliolid species which possesses such a very distinctive test morphology, a spinose keel along the edge of the test, from $\mathrm{FH}_{3} \mathrm{P}_{1}$ Rădăuţi Core, Romanian Basin. Until now, the species $M$. cristata has been recorded in a small number of specimens only in Sarmatian and recent deposits. Curiously, the studied sediment yielded the large number (117) of the specimens occurring in only one sample. This is also the first record of this species in Sarmatian deposits from the Moldavian Platform (northeast Romania). Based on the benthic foraminiferal assemblage changes recorded throughout the succession, we discuss the possible palaeoecology of this exceptional miliolid taxon. Moreover, we debate whether the development of such a special spinose keel could be related to environmental/microhabitat changes.

\section{Geological setting}

The $\mathrm{FH}_{3} \mathrm{P}_{1}$ Core is situated south of the city of Rădăuţi (WGS 84: $47^{\circ} 49^{\prime} 32.34^{\prime \prime} \mathrm{N}, 25^{\circ} 54^{\prime} 27.54^{\prime \prime} \mathrm{E}$ ), northeast Romania. Studied sediments belong to the Moldavian Platform, in the western part of the East European Platform
(Ionesi and Ionesi, 1968; Ionesi, 1968, 1994; Ionesi et al., 2005, fig. 1). The sediments are mostly composed of ashy-grey clays, partially compacted and/or laminated, with some fine intercalations of sand, sandstones and coal films. Ionesi and Ionesi (1968) dated these deposits as early Sarmatian based on the macro- and micro-association with Inaequicostata inopinata (Grischevich) and Obsoletiforma lithopodolica (Dubois) among macrofauna and Cycloforina karreri ovata (Serova), Cycloforina karreri karreri (Venglinski), Elphidiella serena (Venglinski) and Elphidium reginum (d'Orbigny) among foraminifera. The early Sarmatian age of these deposits has been also confirmed by other foraminiferal studies (Ionesi, 1968, 1991; Ionesi and Guevara, 1993).

\section{Material and methods}

In total 27 samples collected from the $\mathrm{FH}_{3} \mathrm{P}_{1}$ Rădăuţi Core, northeast Romania, were analysed for benthic foraminiferal studies. The combined weight of all of the samples was approximately $200 \mathrm{~g}$. The samples were crushed, washed and dried. The residue was sieved through three sieves $(0.466$, 0.263 and $0.122 \mathrm{~mm}$ ) and separated into four fractions for easier microfossil analysis. The majority of the studied specimens were identified in the fraction smaller than $0.263 \mathrm{~mm}$. The specimens were handpicked using a Carl Zeiss Jena SM $\mathrm{XX}$ binocular stereo microscope. In general, foraminiferal tests are very well preserved. Quantitative analysis were based on representative splits of more than 800 specimens and all benthic foraminifera were counted at a generic level. The relative abundance of particular genera is presented in Fig. 2. 


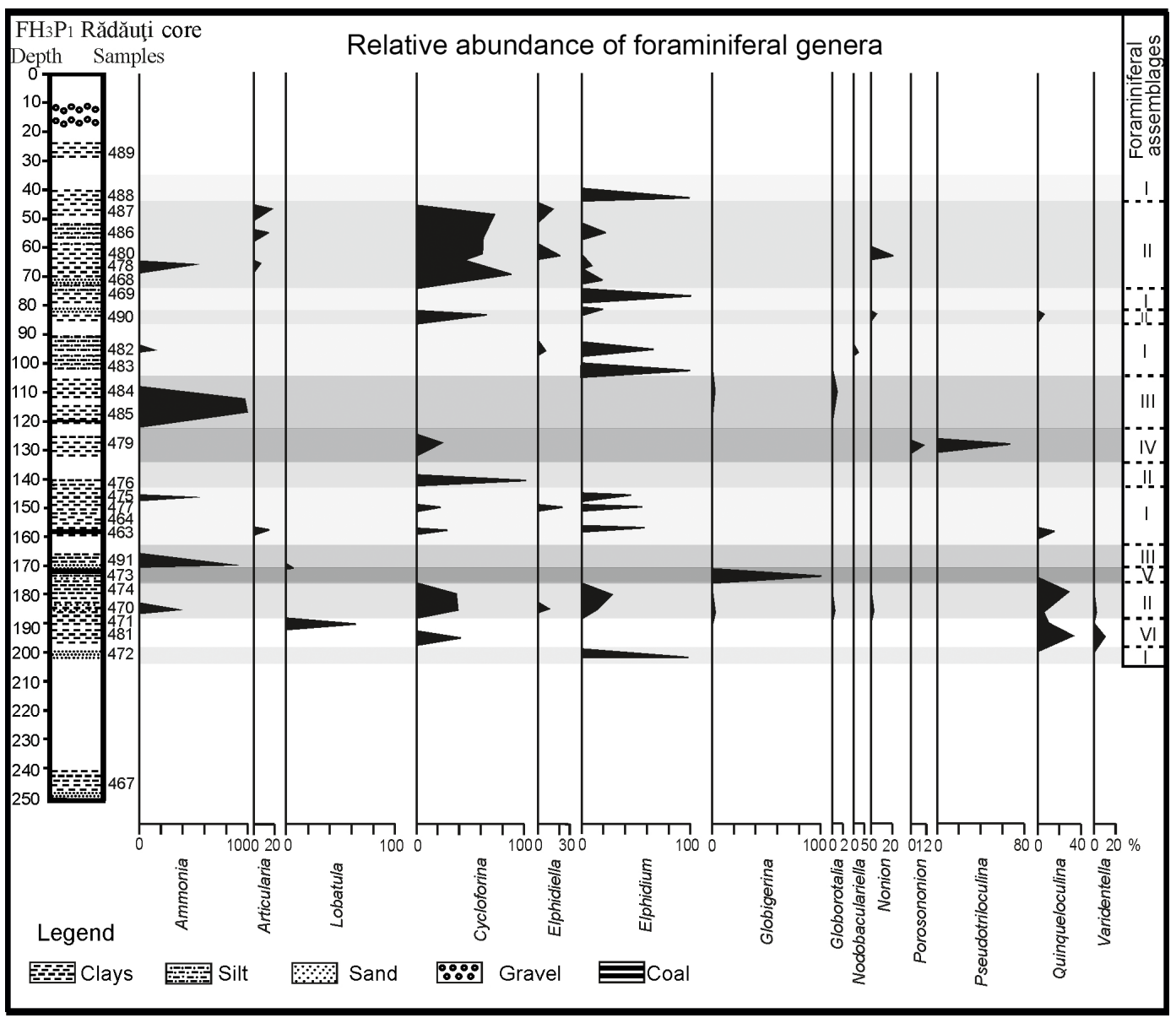

Figure 2. Benthic foraminiferal assemblages of the $\mathrm{FH}_{3} \mathrm{P}_{1}$ Rădăuţi Core section.

We measured the length and width of the test, aperture and tooth of the best preserved specimens (24) of Miliolina cristata (Fig. 3a-c). The length-to-width ratios of the Miliolina cristata specimens were also calculated (Fig. 3d).

SEM images were taken by using a Vega/Tescan SEM microscope in the Faculty of Biology, Alexandru Ioan Cuza University of Iasi, Romania. The thin sections of selected specimens where made in the Faculty of Geology, University of Warsaw, Poland. The investigated material is deposited in the Original Paleontological Collections Museum of Alexandru Ioan Cuza University of Iasi, Romania, under inventory number 7908-8024.

\section{Results}

\section{Benthic foraminiferal assemblages}

Benthic foraminiferal assemblages of the $\mathrm{FH}_{3} \mathrm{P}_{1}$ Rădăuţi Core section are composed of 28 species, which are listed in Appendix A. The most common taxa belong to the striated miliolids Cycloforina karreri ovata, C. karreri karreri, and Cycloforina predcarpatica; to species of the genus Elphid- ium (e.g. Elphidium reginum, Elphidium reussi, Elphidium incertum); and to the species Lobatula lobatula. Numerous specimens of Ammonia beccarii were also identified in most of the analysed samples. Barren samples (samples 464, 489 and 467) are also recorded.

Six foraminiferal morphotypes, named from I to VI, were distinguished based on quantitative analysis (Fig. 2). Assemblage I, comprising the largest number of samples (488, $469,482,483,475,477,463$ and 472), is dominated by the genus Elphidium. Assemblage II (samples 490, 486, 480, $478,468,490,476,474,470$ ) is similar to Assemblage I in the general taxonomic composition (the occurrence of Ammonia, Articularia, Elphidium, Quinqueloculina); however it differs by domination of representatives of the genus Cycloforina, especially ribbed species: C. karreri ovata, C. karreri karreri, C. predcarpatica. The abundant occurrence of the species Ammonia beccarii characterizes Assemblage III, as it composes $98 \%$ of this. The other $2 \%$ of the assemblage is represented by the species Globorotalia miocenica. Assemblage IV is dominated by the single genera Pseudotriloculina (Pseudotriloculina consobrina, Pseu- 

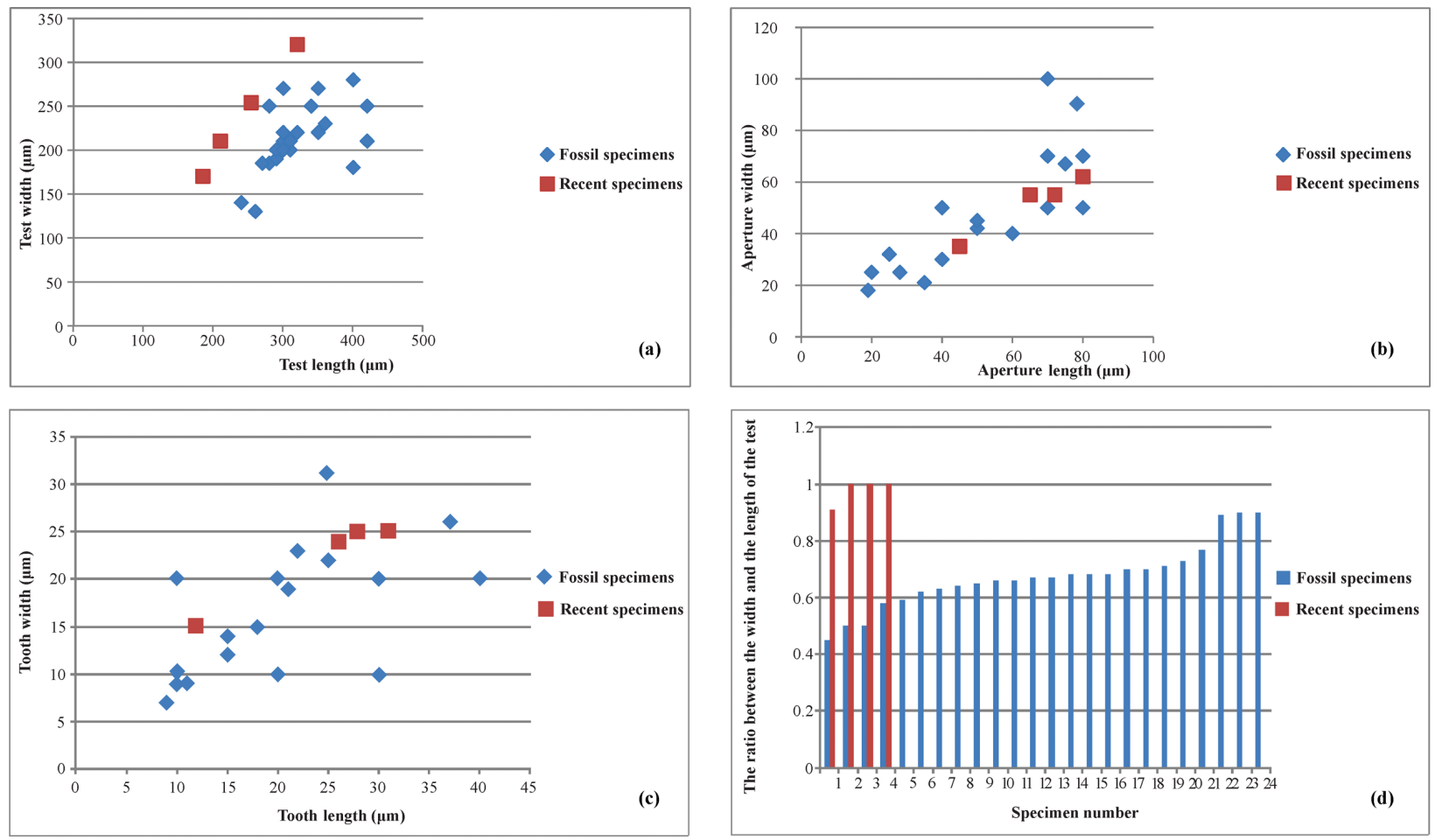

Figure 3. Diagrams of the length and the width measurements of fossil and recent specimens. (a) Test. (b) Aperture. (c) Tooth. (d) Lengthto-width ratio of the test of $M$. cristata.

dotriloculina nitens), which constitutes almost $99 \%$ of the assemblage.

Assemblage V can be observed only in one sample (473, located at a depth of $173 \mathrm{~m}$ ) and is characterized by the presence of only planktonic foraminifera from the genus Globigerina. Assemblage VI is represented by Lobatula lobatula (60\%) followed by species belonging to the genera Quinqueloculina and Varidentella.

The specimens of the species Miliolina cristata have been identified (117 specimens) only in sample 470, located between 184.8 and $186.8 \mathrm{~m}$, and framed in Assemblage II.

\section{Description of Miliolina cristata}

Suprageneric classification follows Loeblich \& Tappan (1987)

Order Miliolida Delage \& Hérouard

Suborder Miliolina Delage \& Hérouard

Superfamily Milioloidea Ehrenberg

Family Hauerinidae Schwager

Genus Miliolina Williamson, 1858

Miliolina cristata Millett, 1898

(Figs. 4a-h, 5a-d)
1898 Miliolina cristata Millett: 506, pl. 12, figs. 3a-c.

1974 Cycloforina cristata (Millett); Łuczkowska: 76, pl. 13, figs. 7a-c.

1995 Cycloforina cf. cristata (Millett); Popescu: 90, pl. 1, figs. 7-9.

2005 Quinqueloculina cristata (Millett); Rajeshwara Rao et al.; 62, pl. 1, figs. a-c.

2007 Cycloforina cristata (Millett); Schütz et al.: 453, pl. 1, figs. $4 \mathrm{a}-\mathrm{c}$.

Type species: Miliolina cristata Millett, 1898, by original designation.

Diagnosis: The test is nearly circular, unequally as dimensions; the chambers are triangular in cross section with the peripheral margin, acute. The last chamber is boldly serrated; aperture with a thickened margin (after Millett, 1898).

Occurrence and age: Early Sarmatian deposits: Moldavian Platform, Rădăuţi Depression, northeast Romania; Zrecze, Poland; Făget Depression, west Romania; southern part of the Vienna Basin, Austria. Recent sediments: Malay Archipelago; Araya, Los Testigos, Caribbean Sea; Cochin, southwest India; Bay of Bengal, southeast India; Chennai, India. 


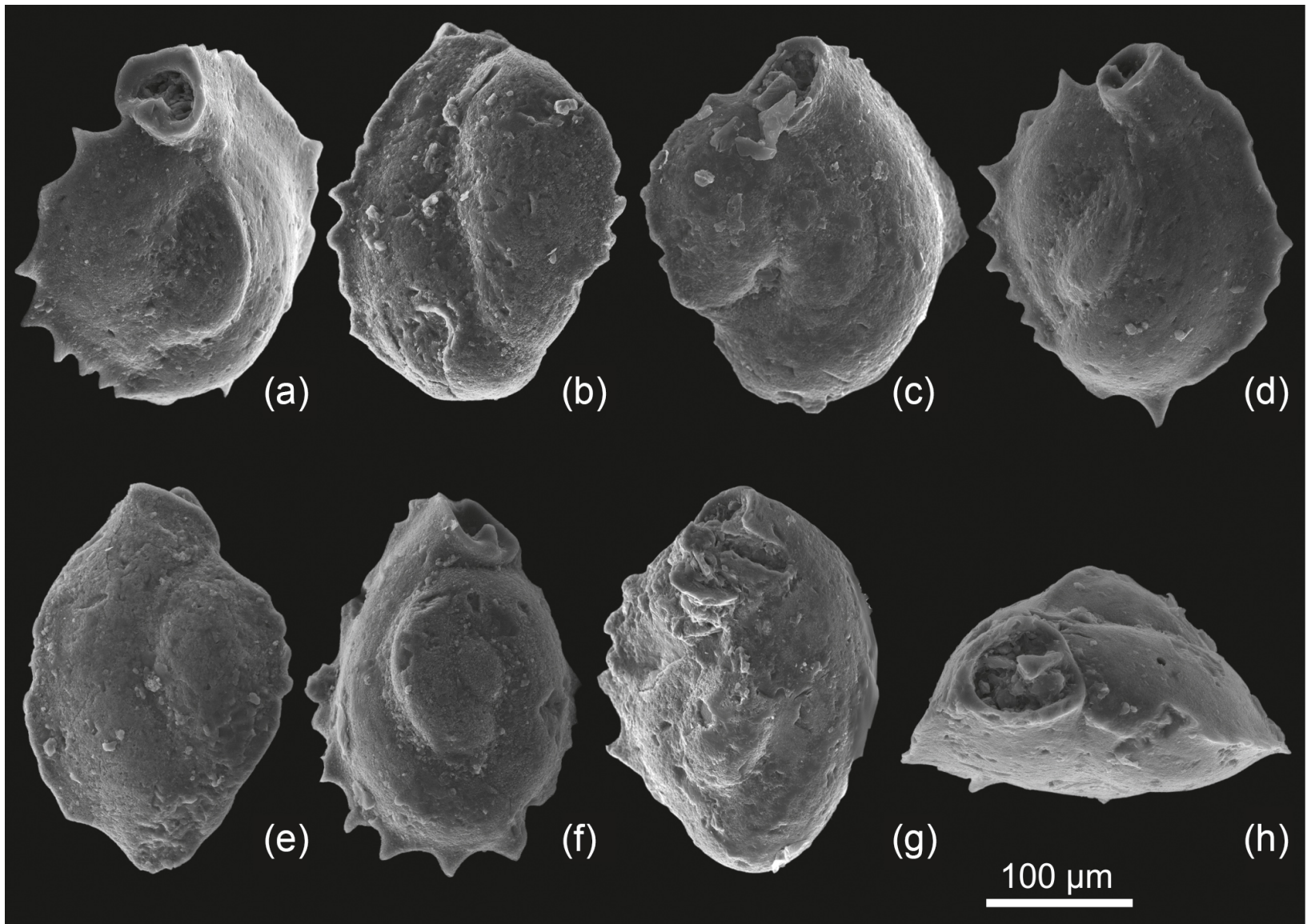

Figure 4. SEM images of the $M$. cristata specimens identified in the $\mathrm{FH}_{3} \mathrm{P}_{1}$ Rădăuţi Core section, sample 470 . (a, b, c, d:) Front side. (f, g) Back side. (h) Apertural view.

\section{Material: 117 well-preserved specimens}

Description: Test calcareous, small and oval with a sharp periphery, thin walls and smooth surface, serrated at the edges. Chambers are slightly inflated; the middle chamber is smaller and presents distinct suture lines. In transversal section, the cambers are triangular. The aperture is circular with a short neck and a simple tooth. The initial growth phase of the tooth can be observed in Fig. 5b.

Measurements: The relatively large number of the specimens recorded allowed us to study the intra-specific variability. We made a series of test measurements on the well-preserved specimens to assess whether there are significant differences in length and the width of the test, aperture and tooth. As presented in the Fig. $3 \mathrm{a}-\mathrm{c}$, the specimens do not display major differences regarding the general dimensions of the test, the aperture and the tooth. The test length is from 240 to $420 \mu \mathrm{m}$ and the test width range between 130 and $280 \mu \mathrm{m}$. The aperture lengths vary between 28 and $80 \mu \mathrm{m}$ and the widths between 28 and $100 \mu \mathrm{m}$. The lengths of the apertural teeth (measured in only complete specimens since some of the teeth were broken) vary between 10 and $40 \mu \mathrm{m}$ and the widths vary between 10 and $20 \mu \mathrm{m}$.

By comparing the dimensions of fossil specimens with the recent specimens found by Rajeshwara Rao et al. (2005) in the Bay of Bengal, we noticed that in general the recent specimens have smaller tests than the fossil ones of Miocene age, with a test length which does not exceed $260 \mu \mathrm{m}$. We also analysed the ratio between width and length of the test (Fig. 3d). Our results show that for recent specimens the ratio is closer to or even one; for fossil specimens this is generally lower, due to their elongation probably because of the more rounded shape of the recent specimens compared to (fossil) Miocene specimens.

Variability: The variability of the species is marked by test edge, developed as spinose-keel-like, which is well developed in some specimens and poorly developed or even invisible in the other specimens. The spines are irregular in shape; their number varies from 5 to 10 on each chamber. On some specimens the spines are uniformly distributed and they are almost equal in size for each chamber while 


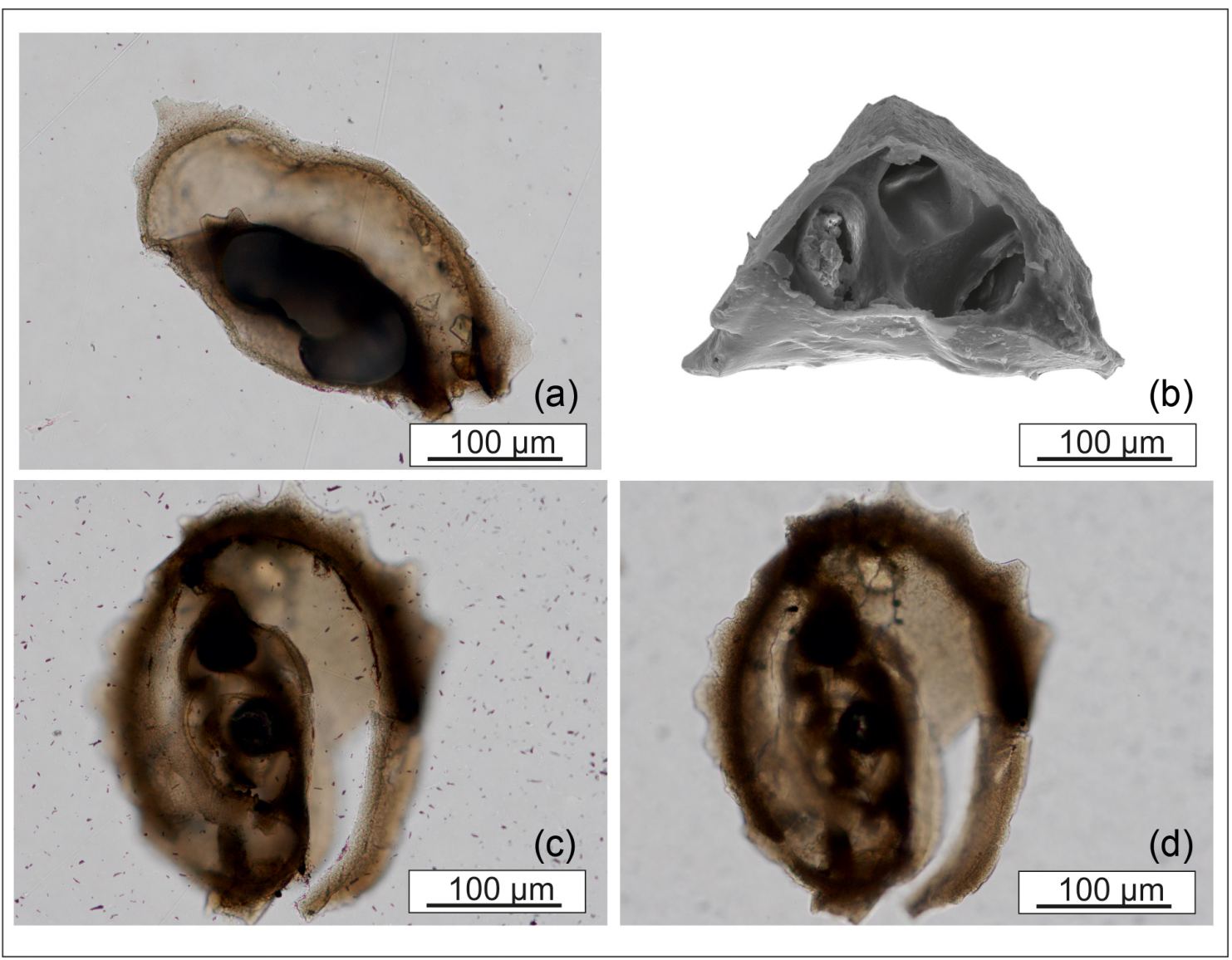

Figure 5. View of the interior of M. cristata tests. (a, c, d) Thin sections. (b) SEM image with the initial growth phase of the tooth.

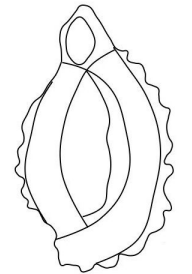

$1(a)$
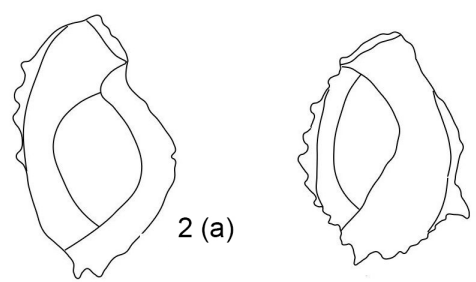

$3($ a)
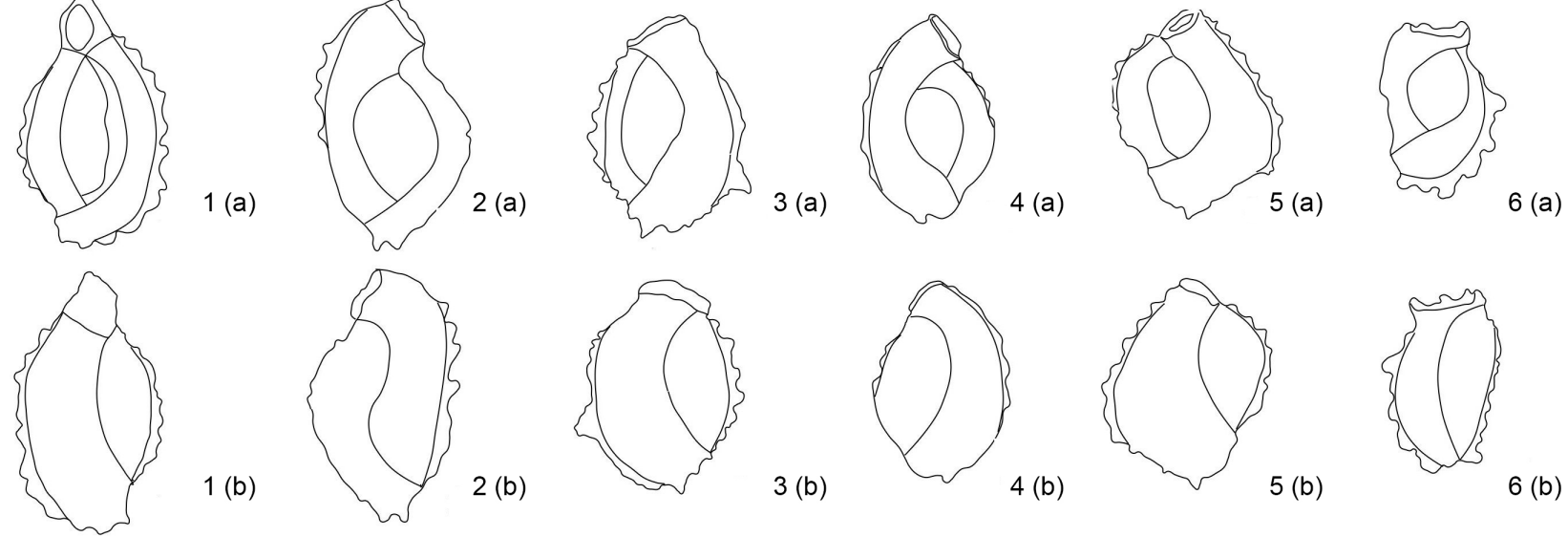

2 (b)

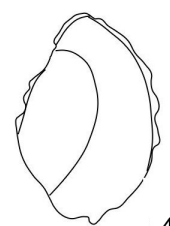

3 (b)

$4(b)$
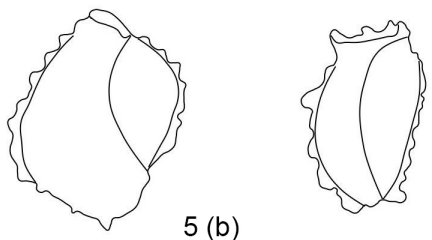

5 (b)

6 (b)
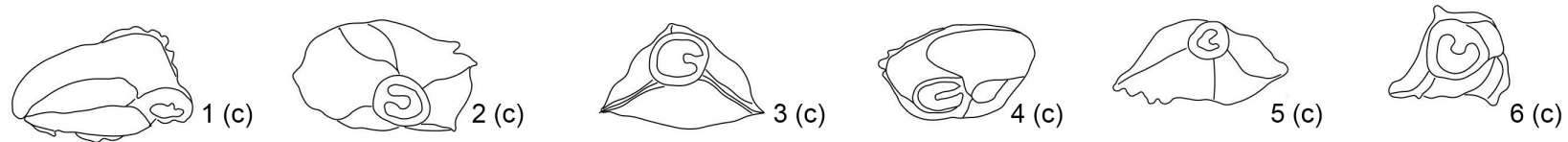

$100 \mu \mathrm{m}$

Figure 6. Drawings of M. cristata. (1a-6a) Front side. (1b-6b) Backside. (1c-6c) Apertural view. 
on others the distribution is irregular (Fig. 6). The spinose keel is well visible on the outside as well as the inside of the chambers. Moreover, we notice that the chambers are longitudinally curved with thin and non-lamellar walls and serrated edges, which is characteristic for this species (Fig. 5).

Remarks: A distinctive feature is represented by the well-developed spinose keeled edges, which can be very clearly or faintly visible in some specimens.

\section{Discussion}

To understand the ecological preferences of Miliolina cristata we analysed the changes of foraminiferal assemblages within the studied succession, since foraminiferal assemblages have been successfully applied for palaeoecological reconstructions using correlations between foraminiferal test shapes and their environmental requirements (Murray, 1984). A number of papers discuss the relationship between foraminiferal distribution within lithological successions and their response to their environmental changes (Atkinson, 1971; Murray, 1973, 1991, 2006; Boltovskoy, 1963; Boltovskoy et al., 1991; Haynes, 1981; Iglikowska and Pawlowska, 2015). Even then, some foraminiferal assemblage changes as well as some specific morphological changes recorded in the fossil material are very difficult to interpret and are not always thoroughly discussed.

In the $\mathrm{FH}_{3} \mathrm{P}_{1}$ Rădăuţi Core section we identified six different foraminiferal assemblages which probably indicate different environmental conditions during sedimentation, especially changeable salinity. The lowest salinity, a brackish environment, seems to be presented by Assemblage III. This assemblage is highly dominated by one species, Ammonia beccarii (Linné), which constitutes $98 \%$ of the assemblage. In general Ammonia beccarii is regarded as a euryhaline species which commonly occurs in brackish and nearshore marine habitats (Hayward and Hollis, 1994). However, recent low-diversity foraminiferal communities dominated by Ammonia beccarii are typical brackish water associations of very shallow environments (Brasier, 1982; Cimerman and Langer, 1991). Additionally, the dominance of Ammonia beccarii is characteristic of intertidal environments (Scott et al., 1980). The general trend of foraminiferal diversity (species richness) decreases with the decreasing salinity (Culver et al., 2012). The lowest number of species in recent foraminiferal communities is observed in lagoonal or deltaic areas where salinity is reduced to less than $2 \%$ o by freshwater input (Sen Gupta, 2003). Assemblage II, displaying still very low diversity and domination of a few species of Elphidium, indicates slightly higher salinity than Assemblage III but still lower than normal marine (compare Hayward and Hollis, 1994). The higher species richness and the abundance of miliolids, which are conspicu- ously rare in brackish lagoons (Murray, 1968, 2006), represented by the genus Cycloforina in assemblages II and IV, indicate increased salinity. Thus, the sediment represented by these foraminiferal assemblages was probably deposited under shallow-water conditions with normal-marine salinity with possible slight fluctuations (compare Filipescu et al., 2014; Roozpeykar and Maghfouri Moghaddam, 2015). Assemblage $\mathrm{V}$, represented only by planktonic species (Globigerina bulloides d'Orbigny and Globorotalia miocenica Palmer), displays normal-marine salinity (Hemleben et al., 1989). The appearance in this interval of planktonic forms, which are dominated by Globigerina - a shallow-water dweller (e.g. Caron and Homewood, 1983) - reflects slightly deeper conditions (Schiebel et al., 1997) but still quite a shallow environment with a depth of dozens of metres (Hart and Bailey, 1979; Leckie, 1987) within the basin. The disappearance of benthic foraminifera in this sample may suggest unfavourable conditions for benthic organisms at the bottom of the sea, most likely a low-oxygen environment. It can be supported by the lithological changes, such as the appearance of coal, which is essentially buried organic matter (Reading, 1996). The abundant presence of the species Lobatula lobatula (Walker \& Jacob) in Assemblage VI may indicate normal-marine salinity and a high-energy environment (Peryt and Jasionowski, 2012). Additionally, it probably displays slightly deeper depths than is represented by assemblages I to IV (Klitgaard Kristensen and Serjup, 1996; Murray, 2006). In summary, $M$. cristata occurs only in one sample in the studied sediments, of which the foraminiferal assemblages indicate normal-marine salinity conditions. Thus the species thrived in similar salinities to other fossil and recent specimens.

\section{Function of spines and spinose keel structures in benthic foraminifera}

It is widely known that benthic foraminifera can develop a variety of exoskeletal test features (e.g. pseudo-spines, spikes, pustules, ribs, cancellate surface) that support adaptation to specific microhabitats (Wright, 1968; Murray, 1973, 1991; Boltovskoy and Wright, 1976; Poag, 1982; Boltovskoy et al., 1991; Altenbach et al., 1993; Langer, 1993; Hottinger, 2000). Spines are quite often observed in Rotalida (Buliminidae (Bulimina echinata, Bulimina mexicana, Bulimina striata, Bulimina marginata, Bulimina aculeata), Calcarinidae (Calcarina mayori, Calcarina defrancii, Calcarina gaudichaudii, Calcarina hispida, Calcarina spengleri), Elphidiidae (E. reginum and E. aculeatum)) and Lagenida (Vaginulinidae (Lenticulina costata, Lenticulina denticulifera, Lenticulina formosa, Lenticulina echinata, Fissurina longispina, Fissurina unguiculata)), and are much more rare within Miliolida. Until now, there have only been a few miliolid species described which possess such ornaments: Miliolina cristata, Miliolina excisa, Miliolina calcarata, Pyrgo denticulina and Pyrgo serrata. 
Spines are generally believed to serve different functions in benthic foraminifera. They can be related to pseudopodial flow to deflect pseudopodia away from the shell (Hottinger, 2000). This is well seen in highly motile infaunal taxa, such as bolivinids and buliminids, which possess a whole test covered by the ornament, in which the pseudopodial sheath envelopes the shell on all sides and serves as a kind of burrowing motility (Hottinger, 2000). The other function of this radial dimension pseudopodial flow provided by spines can be to attach to substrates. This attachment system has been observed in various epiphytic species (Langer, 1993) such as the species Elphidium aculeatum in which spines may aid efficient extrusion of pseudopodial networks. Langer (1993) shows that microhabitat and substrate preferences of epiphytic foraminifera are usually reflected in the test shape. Adaptive features developed by foraminifera serving as devices for the substrate attachment have been identified not only in recent epiphytic foraminifera but also in their fossil counterparts. The species Vasiglobulina reticulata developed an advanced mode of attachment by extending several calcified acicular "pillars" or "stelae", which are not present in the motile phenotype of this species, and can be constructed at any place on the external part of the test (for details see Poag, 1982). In addition, Peryt and Jasionowski (2012, cf. Tóth et al., 2010) state that the long spines at the periphery of the test of the species Elphidium reginum are a morphological adaptation from the algal to seagrass substratum. Moreover, the spines of calcarinids (symbiont-bearing so-called larger foraminifera), associated with a radially arranged canal system, are necessary for pseudopodia formation, excretion, attachment to the substratum, protection and probably also growth and reproduction (Röttger and Krüger, 1990). Additionally, the spines and spicules of some benthic foraminifera may serve as protective devices or may directly stabilize their shell in mobile sediments (Boltovskoy and Wright, 1976; Hottinger, 2000). The relationship between the substrate and the test morphology has been recognized, especially in agglutinated foraminifera, but also in some calcareous forms (e.g. Saidova, 1953; Thayer, 1975; Boltovskoy and Wright, 1976). For instance, Boltovskoy and Wright (1976) suggested that the spines and/or spicules of the benthic species Baculogypsina sphaerulata and Meandroloculina aculeata may be used as a protective device or may serve as a mechanism for maintaining stability on soft bottoms. Hottinger (2000) shows that some foraminiferal species like Brizalina simpsoni, which live in sandy coarse-grained sediments, can develop ribs or pseudospines for maintaining their position among the grains when the foraminifera harvests the meioflora or fauna for food. Medioli and Scott (1978) also postulated that Discanomalina semipunctata formed irregular spines to better adapt to living in coarse sediments within a high-energy environment, and Delaca and Lipps (1972) suggest that the species Rosalina globularis attaches to the substrate by organic membrane as an adaption to high-energy environments.
Similar test adaptations to highly turbulent conditions were marked by Lipina (1961), who proposed the general rule that benthic foraminifera occupying highly turbulent environments display some kind of reinforcements, such as supplementary endoskeletons and thicker walls. In addition, Langer and Lipps (2003) claim that the different test ornamentation (e.g. strongly thickened peripheral margins, massive ribs, robust spines) on some foraminifera species is also a morphological adaptation to turbulence and highenergy water. Moreover, Arslan et al. (2016) and Burke and Hull (2017) sustain the fact that species of foraminifera which present a keel are more resistant to breakage and this is the reason why they are more abundant in shallow waters and in sandy substrates.

The functions of test ornaments (including spines) of miliolids are very poorly understood. Since miliolids possess porcellaneous imperforate tests, the spine functions are not in association with pseudopodial flow. Most of the interpretations of these miliolid exoskeletal features are apparently related to the test stabilization in sandy sediments. For instance, Bermúdez and Seiglie (1963) found some regularity in the miliolids of the Gulf of Cariaco, Venezuela, which is that the species which occupy a sandy substrate possess striated, polygonal and wedge-shaped chambers, whereas those occupying clayey sediments are characterized by unornamented and smooth tests. Moreover, Bogdanowicz (1952) similarly postulated that miliolid taxa living in turbulent water often possess thick walls, a persistent rim and fimbrate sutures. In general the recent keeled M. cristata was recorded from sandy and high-energy environments (Seibold, 1975; Seibold and Seibold, 1981), as are taxa such as Miliolina calcarata and M. excisa, which are very similar to the species Miliolina cristata (Brady et al., 1888; Heron-Allen and Earland, 1922).

Some benthic foraminifera can also develop other structures such as pustules and tubes for food acquisition; however there is no record of this function in relation to spines. For example, the miliolid species Miliolina subrotunda constructs a long detritic tube at the top of the test which allows the organism to feed in the particle stream above the sediment (Altenbach et al., 1993).

\section{Miliolina cristata Millett}

Miliolina cristata Millett is a miliolid species which possesses very distinctive test morphology, namely it forms a spinose keel, along the edge of the test. This taxon is very rare within Miocene as well as recent sediments and is recorded for the first time in Sarmatian deposits from Moldavian Platform. Until now, this species has been reported in small numbers in Sarmatian deposits from Zrecze, Poland (Łuczkowska, 1974), the Făget Depression, Romania (Popescu, 1995), and from the southern part of the Vienna Basin (Schütz et al., 2007). The authors assigned this species to the genus Cycloforina. In recent sediments, this 
taxon is also very rare. Millett (1898) identified one specimen (the holotype) in the Malay Archipelago and named the taxon Miliolina cristata. Later, this foraminifer was found only by Seiglie (1966, 1967 after Culver and Buzas, 1982) in the shelf sediments from Araya, Los Testigos, Caribbean Sea, by Seibold (1975), in the near-shore area of Cochin (southwest India), and by Rajeshwara Rao et al. (2005) in the Bay of Bengal and Suresh Gandhi et al. (2013), who identified this species in estuarine sediments from Chennai. All the authors who have identified this species in recent sediments attributed it to the genus Quinqueloculina.

In the studied material a large number of Miliolina cristata (117 specimens) have been found in only one sample (470). The reason for the appearance of these unique spinose foraminifera remains unresolved. Some specific favourable environmental conditions for $M$. cristata must have appeared. The curious thing about this species is whether $M$. cristata is a new species as described by Millett (1898) or whether the spinose edge is a morphological adaptation as a response to an appearance of some new environmental conditions of the miliolid species living in the basin. We suspect that Miliolina cristata could be an ecophenotype of some miliolid species, possibly Quinqueloculina akneriana since this species presents a higher degree of variability and many transitional forms (for details see Łuczkowska, 1974). Test construction in foraminifera seems to be particularly sensitive to environmental conditions (Yanko et al., 1998; Samir and El-Din, 2001) and some of the foraminiferal species are known to display ecophenotypes (Szczechura, 1982, 2000; Moodley and Hess, 1992; Kitazato et al., 2000; Murray, 2006; Tsuchiya et al., 2008, 2009) as a result of specific habitat or changes in the environmental conditions (Haynes, 1991). For example, some specimens of the species Quinqueloculina milleti develop a great variation in their surface ornamentation under different conditions, especially salinity and pollution (Wright, 1968). Moreover, Boltovskoy and Wright (1976) show some specimens of the species Bulimina patagonica with and without spines (described by Cushman and Wickenden, 1929, as Bulimina patagonica var. glabra). Boltovskoy and Wright (1976) also recorded some specimens of $B$. patagonica having only a few spines or even no spinose ornamentation. Tsuchiya et al. (2009) reveal that pore morphology of the species Virgulinella fragilis depends on environmental conditions similarly to the pores of the species Ammonia beccarii (see Moodley and Hess, 1992). In addition Kitazato et al. (2000) show that the presence of the peripheral spines of the benthic species Planoglabratella nakamuray varies with the growth stage and with the environmental conditions. Accordingly, the test ornamentation is not always a diagnostic species feature and thus Miliolina cristata can possibly be an ecophenotype of the species Quinqueloculina akneriana as a result of the appearance of new palaeoenvironmental conditions.

If the taxon was a distinct species it would have migrated from other parts of the basin. The possible area from where the taxon could have migrated is difficult to assess since the species is extremely rare. In the entire Carpathian foreland basin, it was noticed only in very short intervals in three other localities of Poland, Romania and Austria (Euczkowska, 1972; Popescu, 1995; Schütz et al., 2007). Apart from the Sarmatian, the species occurs only in the recent deposits of the Malay Archipelago, Caribbean Sea, and off southwest India, and therefore there are not enough data to discuss its possible migration path and palaeobiogeography. However, the exact function of the spinose morphological feature is still unclear. In general, miliolids are commonly known as epifaunal and epiphytic organisms that have low requirements with respect to water salinity. They can thrive in normalmarine environments such as open-shelf, brackish and hypersaline lagoons, marine marsh and even, though seldom, bathyal depths (mostly Pyrgo). Nevertheless, their frequent occurrences are restricted to distinctive depths and temperatures (Łuczkowska, 1972, 1974; Neagu, 1979; Murray, 1991, 2006; Sen Gupta, 2003).

The fossil specimens of $M$. cristata were described from the clays and marls; however, the authors did not present the lithology in detail, nor did they discuss the palaeoecology of the species, rather focusing only on the foraminiferal taxonomy and stratigraphy. M. cristata in the Polish Basin (Euczkowska, 1972) co-occurs with many other miliolid taxa (Varidentella pseudocostata (Venglinski), Varridentella rotunda (Gerke), Articulina problema (Bogdanowicz)) and many elphidiids (Elphidium josephinum (d'Orbigny) and Elphidium jukuovi Serova), suggesting normal-marine salinity conditions.

The ecology of the recent spinose miliolid M. cristata was postulated based only on findings of empty tests, and there is no reference to live specimens (Millett, 1898; Seibold, 1975; Rajeshwara Rao et al., 2005; Suresh Gandhi et al., 2013). Seibold (1975) identified the species M. cristata in the Cochin area, southwest India, in one sample, collected from offshore sandy deposits of 20-30 m depth, and roughly $19 \mathrm{~km}$ from the shoreline. According to Seibold and Seibold (1981) this area is represented by a high-energy environment strongly influenced by the southwest monsoon, which begins in May/June and ends in August/October. Due to abundant rainfall in June and July $(1500 \mathrm{~mm})$, the salinity of surface offshore water, which normally is $34.5 \%$, is lowered to 15-20 and even $8 \%$ close to the shoreline. Rajeshwara Rao et al. (2005) identify the species Miliolina cristata in the Bengal Bay shelf sands, between 21 and $38 \mathrm{~m}$ depth. The authors claim that this species is probably epifaunal, preferring a sandy substratum, and is perhaps confined to the inner shelf. Suresh Gandhi et al. (2013) also described the species from the sandy sediments of Adyar River from Chennai, India. Accordingly, in general the recent $M$. cristata was found in sandy and high-energy environments. This is in accordance with the one of the main spine functions, interpreted from different taxa, which is to maintain test position among the coarse-grained sediments within a high- 
energy environment (Poag, 1982; Röttger and Krüger, 1990; Hottinger, 2000; Medioli and Scott, 1978) (see the second part of the discussion). In the studied material the species $M$. cristata also occurs in sandy-grained sediments (clays with sandy intercalations), which indicate a temporary energy increase within the basin. Moreover, the next sample, located less than $1 \mathrm{~m}$ below, is dominated by Lobatula lobatula what strongly supports a high-energy environment being present in this interval (Murray, 2006). Accordingly, the species $M$. cristata recorded in the studied material may develop this spinose keel as a response to the appearance of sandy substratum and a higher-energy environment similarly to recent counterparts (Seibold, 1975; Seibold and Seibold, 1981; Rajeshwara Rao et al., 2005; Suresh Gandhi et al., 2013); however we cannot exclude other alternatives. The other possible option would be that the spines serve as attachment devices just as in epiphytic calcarinids or elphidiids.

\section{Conclusions}

The present study analyses the foraminiferal assemblages from $\mathrm{FH}_{3} \mathrm{P}_{1}$ Rădăuţi Core Section, from the northwestern part of the Moldavian Platform, Romania. Twenty-seven samples are analysed, and we identified more than 800 specimens belonging to 28 foraminifera, which have been grouped into six assemblages. The foraminiferal assemblages are mainly dominated by the presence of rotaliids and miliolids indicating shallow water and even marginal marine environments. Changes in benthic foraminiferal assemblage composition display fluctuations of salinity during sedimentation from brackish to normal marine. Some short and rather small sea-level changes are also observed, characterized by the increase in the sea level.
We present, for the first time from the Moldavian Platform, a very rare miliolid species, Miliolina cristata, which is represented by 117 specimens recorded only in one sample. This species has been described so far in only a few papers: from Sarmatian deposits from Poland, Romania and Austria and from recent sediments from the Malay Archipelago, Caribbean Sea and India. The species $M$. cristata possesses a distinctive morphological feature which is very rare within the miliolids: a spinose keel at the periphery of the test. The detailed analyses of test morphology and its variability, observed in the picked specimens as well as in thin sections, revealed the fact that the development of this special morphological feature was probably a response to the appearance of new, more turbulent environmental conditions. Our observations support the assumption that the miliolid spinose keel served to stabilize the foraminiferal test in the sandy substrate in relatively high-energy environments. We also suspect that Miliolina cristata could be an ecophenotype of some other miliolid species, most probably Quinqueloculina akneriana.

Data availability. All data are included in this paper. 


\section{Appendix A: Taxonomical appendix}

Taxonomic reference list for all species recorded in the studied section. The species are listed alphabetically by genus name.

1. Ammonia beccarii (Linné, 1758)

2. Articularia karreriella (Venglinski, 1958)

3. Cycloforina fluviata (Venglinski, 1958)

4. Cycloforina predcarpatica (Serova, 1955)

5. Cycloforina karreri ovata (Serova, 1955)

6. Cycloforina karreri karreri (Reuss, 1869)

7. Elphidium aculeatum (d'Orbigny, 1846)

8. Elphidium incertum Williamson, 1858

9. Elphidium macellum macellum (Fitchel and Moll, 1803)

10. Elphidium reginum d'Orbigny, 1846

11. Elphidium reussi Marks, 1951

12. Elphidium subumbilicatum Czjzek, 1848

13. Elphidiella serena (Venglinski, 1958)

14. Globigerina bulloides d'Orbigny, 1846

15. Globorotalia miocenica Palmer, 1945

16. Lobatula lobatula (Walker and Jacob, 1978)

17. Miliolina cristata Millett, 1898

18. Nodobaculariella ovalis Venglinski, 1958

19. Nodobaculariella sulcata (Reuss, 1850)

20. Nonion bogdanowiczi Voloshinova, 1952

21. Porosononion subgranosus (Egger, 1857)

22. Pseudotriloculina consobrina (d'Orbigny, 1846)

23. Pseudotriloculina consobrina nitens (Reuss, 1850)

24. Quinqueloculina akneriana d'Orbigny, 1846

25. Quinqueloculina akneriana argunica Gerke, 1938

26. Quinqueloculina minakovae ukrainica Didkowski, 1961

27. Varidentella pseudocostata (Venglinski, 1958)

28. Varidentella rotunda (Gerke, 1938) 
Competing interests. The authors declare that they have no conflict of interest.

Acknowledgements. This work was funded by grant number UMO-2013/09/D/ST10/04059 from the National Science Centre $(\mathrm{NCN})$. The authors wish to express their gratitude toward Nandamuri Rajeshwara Rao (University of Madras) and Sergiu Adi Loghin for the bibliographic information (Alexandru Ioan Cuza University of Iasi). We are indebted to the anonymous reviewers for suggestions that helped us to considerably improve our manuscript.

Edited by: Laia Alegret

Reviewed by: two anonymous referees

\section{References}

Altenbach, A. V., Heeger, T., Linke, P., Spindler, M., and Thies, A.: Miliolinella subrotunda (Montagu), a miliolid foraminifer building large detritic tubes for a temporary epibenthic lifestyle, Mar. Micropaleontol., 20, 293-301, 1993.

Arslan, M., Kaminski, M. A., Tawabini, B., and Frontalini, F.: Benthic foraminifera in sandy (siliciclastic) coastal sediments of the Arabian Gulf (Saudi Arabia): a technical report, Arab. J. Geosi., 9, 1-7, 2016.

Atkinson, K.: The relationship of Recent foraminifera to the sedimentary facies in the turbulent zone Cardigan Bay, Wales, J. Nat. Hist., 5, 385-439, 1971.

Bermudez, P. J. and Seiglie, G. A.: Distribucion de los foraminiferos del Golfo de Cariaco, Boletin de Institute de Oceanographica de Universidad Oriente, 2, 1-267, 1963.

Bogdanowicz, A. K.: Miliolidy i peneroplidy. Iskopaemye foraminifery. Trudy Vnigri, 64, 1-138, 1952.

Boltovskoy, E.: Foraminiferos y sus relaciones con el medio, Revista de Hidrobiologia, V, 21-109, 1963.

Boltovskoy, E. and Wright, R.: Recent Foraminifera, Junk Publication, The Hague, 1976.

Boltovskoy, E., Scott, D. B., and Medioli, F. S.: Morphological variations of benthic foraminiferal tests in response to changes in ecological parameters-a review, J. Paleontol., 65, 175-185, 1991.

Brady, B. H., Parker, K. W., and Jones, R. T.: On some foraminifera the Aborhls Bank, Transactions of the Zoological Society of London, 12, 211-239, 1888.

Brasier, M. D.: Architecture and evolution of the foraminiferid testa theoretical approach, in: Aspects of Micropaleontology, edited by: Banner, F. T. and Lord, A. R., 1-41, Allen and Unwin, London, 1982.

Buosi, C., Frontalini, F., Da Pelo, S., Cherchi, A., Coccioni, R., and Bucci, C.: Foraminiferal proxies for environmental monitoring in the polluted lagoon of Santa Gilla (Cagliari, Italy), Present Environment and Sustainable Development, 4, 91-104, 2010.

Burke, J. E. and Hull, M.: Effect of gross morphology on modern planktonic foraminiferal test strength under compression, J. Micropalaeontology, 36, 174-182, https://doi.org/10.1144/jmpaleo2016-007, 2017.

Caron, M. and Homewood, P.: Evolution of the early planktic foraminifera, Mar. Micropaleontol., 7, 453-462, 1983.
Cimerman, F. and Langer, M. R.: Mediterranean foraminifera, Academia Scientarium et Artium Slovenica, Dela Opera 30, Classis IV: Historia Naturalis, Ljubljiana, 1991.

Corliss, B. H.: Microhabitats of benthic foraminifera within deepsea sediments, Nature, 314, 435-438, 1985.

Corliss, B. H. and Fois, E.: Morphotype Analysis of Deep-Sea Benthic Foraminifera from the Northwest Gulf of Mexico, Palaios, 5, 589-605, 1990.

Culver, S. F. and Buzas, M. A.: Distribution of recent benthic foraminifera in the Carribean area, Smithsonian Contributions to the Marine Sciences, 14, 1-382, 1982.

Culver, T., Mallinson, D. J., Corbett, D. R., Leorri, E., Rouf, A. A., Azhar, N., Shazili, M., Yacob, R., Whittaker, J. E., Buzas, M. A., and Parham, P. R.: Distribution of foraminifera in the Setiu estuary and lagoon, Terengganu, Malaysia, J. Foramin. Res., 42, 109-133, 2012.

Cushman, J. A. and Wickenden, R. T. S.: Recent Foraminifera from off Juan Fernandez Islands, Proceedings U.S. National Museum, 75, 1-16, 1929.

Delaca, T. E. and Lipps, J. H.: The mechanism and adaptive significance of attachment and substrate pitting in the foraminiferan Rosalina globularis (d’Orbigny), J. Foramin. Res., 2, 68-72, 1972.

Dubicka, Z., Złotnik, M., and Borszcz, T.: Test morphology as a function of behavioral strategies-inferences from benthic foraminifera, Mar. Micropaleontol., 116, 38-49, 2015.

Filipescu, S., Miclea, A., Gross, M., Harzhauser, M., Zagorsek, K., and Jipa, C.: Early Sarmatian paleoenvironments in the easternmost Pannonian Basin (Borod Depression, Romania) revealed by the micropaleontological data, Geol. Carpath., 65, 67-81, 2014.

Hart, M. B. and Bailey, H. W.: The distribution of planktonic Foraminiferida in the mid-Cretaceous of NW Europe. Aspekte der Kreide Europas, IUGS, Series A, 6, 527-542, 1979.

Haynes, J. R.: Foraminifera, Macmillan Publishers Limited, London, 1981.

Haynes, E. M.: Distribution of benthic foraminifera in the Dump Reef area, San Salvador Island, Bahamas, Fourth Keck Research Symposium in Geology, 4, 66-69, 1991.

Hayward, B. W. and Hollis, C. J.: Brackish foraminifera in New Zealand: A taxonomic and ecologic review, Micropaleontology, 40, 185-222, 1994.

Hemleben, C., Spindler, M., and Anderson, O. R.: Modern Planktonic Foraminifera, Springer, Heidelberg, 1989.

Heron-Allen, E. and Earland, A.: British Antarctic ("Terra Nova") Expedition, 1910. Protozoa, Foraminifera-part II. Natural History Report, Zoology, 6, 25-268, 1922.

Hottinger, L.: Functional morphology of benthic foraminiferal shells, envelopes of cells beyond measure, Micropaleontology, 46, 57-86, 2000.

Iglikowska, A. and Pawlowska, J.: The adaptations of the foraminifera and ostracoda to fresh water colonisation, in: Impact of Climate Changes on Marine Environments, edited by: Zielinski, T., Weslawski, M., and Kulinski, K., GeoPlanet Earth Plan., 22, 91-113, 2015.

Ionesi, B.: The stratigraphy of the Miocene platform deposits between Siret Valley and Suceava Valley (Moldavian Platform), Romanian Academy Publisher, Bucharest, 1968. 
Ionesi, B.: Biozonation of the Sarmatian from Moldavian Platform, The Celebration Days of “Al. I. Cuza”, University of Iasi, 25-26, 1991.

Ionesi, B. and Guevara, I.: Studiul depozitelor sarmaţiene din forajul 1002 Badeuti (NV Platformei Moldoveneşti), Geological Bulletin of Romanian Society, 14, 79-87, 1993.

Ionesi, B. and Ionesi, L.: Contributions to the knowledge of the Buglovian between Siret Valley and Suceava Valley (Moldavian Platform), Scientific Annals of "AI. I. Cuza”, University of Iasi, Geology-Geography, 14, 69-78, 1968.

Ionesi, L.: The Geology of platform units and North-Dobrogean Orogen, Tehnique, Bucharest, 1994.

Ionesi, L., Ionesi, B., Rosca, V., Lungu, A., and Ionesi, V.: Middle and Upper Sarmatian on Moldavian Platform, Romanian Academy Publisher, Bucharest, 2005.

Jones, R. W. and Charnock, M. A.: Morphogroups of agglutinating foraminifera. Their life position, feeding habits and potential applicability in (paleo) ecological studies, Revue de Paléobiologie, 4, 311-320, 1985.

Kitazato, H., Tsuchiya, M., and Takahara, K.: Recognition of breeding populations in foraminifera: an example using the genus Glabratella, Paleontology Research, 4, 1-15, 2000.

Klitgaard Kristensen, D. H. and Serjup, H. P.: Modern benthic foraminiferal biofacies across the northern North Sea, Sarsia, 81, 97-106, 1996.

Langer, M. R.: Epiphytic foraminifera, Marine Micropaleontol., 20, 235-265, 1993

Langer, M. R. and Lipps, J. H.: Foraminiferal distribution and diversity, Madang Reef and Lagoon, Papua New Guinea, Coral Reefs, 22, 143-154, 2003.

Langer, M. R., Hottinger, L., and Huber, B.: Functional morphology in low-diverse benthic foraminiferal assamblages from tidal flats of the North Sea, Senck. Marit., 20, 81-99, 1989.

Leckie, R. M.: Paleoecology of mid-Cretaceous planktonic foraminifera: A comparison of open ocean and epicontinental sea assemblages, Micropaleontology, 33, 164-176, 1987.

Linke, P.: Metabolic adaptations of deep-sea benthic foraminifera to seasonally varying food input, Mar. Ecol.-Prog. Ser., 81, 51-63, 1992.

Lipina, O. A.: Zavisimost foraminifer ot fathij v otlozhenijakh famenskogo jarusa verkhnego devona I turnejskogo jarusa karbona zapadnogo sklona Urala, Voprosy Micropaleontologii, 5, 147161,1961

Loeblich, A. R. and Tappan, H.: Suprageneric classification of the Foraminiferida (Protozoa), Micropaleontology, 30, 1-70, 1984.

Loeblich, A. R. and Tappan, H.: Foraminiferal genera and their classification, Van Nostrand Reinhold, New York, 1987.

Longet, D. and Pawlowski, J.: Higher-level phylogeny of foraminifera inferred from the RNA Polymerase II (RPB1) gene, Eur. J. Protistol., 43, 171-177, 2007.

Łuczkowska, E.: Miliolidae (Foraminiferida) from Miocene of Poland, part I. Revision of the classification, Acta Palaeontol. Pol., 17, 342-377, 1972.

Łuczkowska, E.: Miliolidae (Foraminiferida) from Miocene of Poland, part II. Biostratigraphy, palaeoecology and systematics, Acta Palaeontol. Pol., 19, 1-176, 1974.

Medioli, F. S. and Scott, D. B.: Emendation of the genus Discanomalina Asano and its implications on the taxonomy of some attached foraminiferal forms, Micropaleontology, 24, 291-302, 1978.

Mellis, R. and Covelli, S.: Distribution and morphological abnormalities of recent foraminifera in the Marano and Grado Lagoon (North Adriatic Sea, Italy), Mediterr. Mar. Sci., 14, 435-450, 2013.

Millett, F. W.: Report on the Recent Foraminifera of the Malay Archipelago collected by Mr. A. Durrand, part I and II, Journal of the Royal Microscopical Society, 2, 500-518, 1898.

Moodley, L. and Hess, C.: Tolerance of infaunal benthic foraminifera for low and high oxygen concentrations, Biol. Bull., 183, 94-98, 1992.

Murray, J. W.: Ecological experiments on foraminifera, J. Mar. Biol. Assoc. UK, 43, 621-642, 1963.

Murray, J. W.: Living foraminifera of lagoon and estuaries, Micropaleontology, 14, 435-455, 1968.

Murray, J. W.: Distribution and ecology of living benthic foraminiferids, Heinemann, London, 1973.

Murray, J. W.: Benthic foraminifera: some relationship between ecological observations and palaeoecological interpretations, Benthos '83, 2nd International Symposium of Benthic Foraminifera, Pau and Bordeaux, 465-469, 1984.

Murray, J. W.: Ecology and palaeoecology of benthic foraminifera, Logman Scientific and Technical, Harlow, 1991.

Murray, J. W.: The structure and functional significance of the wall of Textularia crenata Cheng and Zheng 1978 (Foraminiferida, Textulariina), Micropaleontology, 40, 267-273, 1994.

Murray, J. W.: Ecology and applications of benthic foraminifera, Cambridge University Press, Cambridge, 2006.

Neagu, T.: Micropaleontology, Tehnique Publisher, Bucharest, 1979.

Pawlowski, J. and Holzmann, M.: Molecular phylogeny of Foraminifera-a review. Eur. J. Protistol., 38, 1-10, 2002.

Pawlowski, J., Bolivar, I., Fahrni, J., and Zaninetti, L.: Taxonomic identification of foraminifera using ribosomal DNA sequences, Micropaleontology, 40, 373-377, 1994.

Pawlowski, J., Holzmann, M., Berney, C., Fahrni, J., Gooday, A. J., Cedhagen, T., Habura, A., and Bowser, S. S.: The evolution of early Foraminifera, P. Natl. Acad. Sci. USA, 100, 11494-11498, 2003.

Pawlowski, J., Holzmann, M., and Tyszka, J.: New supraordinal classification of Foraminifera: Molecules meet morphology, Mar. Micropaleontol., 100, 1-10, 2013.

Peryt, D. and Jasionowski, M.: Sarmatian foraminiferal assemblages of cavern fillings in the Badenian reefs of Medobory (Polupanivka, western Ukraine), Biuletyn Państwowego Instytutu Geologicznego, 449, 175-184, 2012.

Pillet, L., Fontaine, D., and Pawlowski, J.: Intra-genomic ribosomal RNA polymorphism and morphological variation in Elphidium macellum suggests inter-specific hybridization in foraminifera, PLoS One, 7, 1-9, 2012.

Pillet, L., Voltski, I., Korun, S., and Pawlowski, J.: Molecular phylogeny of Elphidiidae (foraminiferida), Mar. Micropaleontol., 103, 1-14, 2013.

Poag, C. W.: Environmental implications of test to substrate attachment among some modern sublittoral foraminifera, Geol. Soc. Am. Bull., 93, 252-268, 1982.

Polovodova, I. and Schönfeld, J.: Foraminiferal test abnormalities in the western Baltic Sea, J. Foramin. Res., 38, 318-336, 2008. 
Popescu, G.: Contribution to the knowledge of the sarmatian foraminifera of Romania, Romanian Journal of Paleontology, 76, 85-98, 1995.

Rajeshwara Rao, N., Nandhakumar, S., and Moorthy, G. M.: Quinqueloculina cristata (Millett) - A rare miliolid foraminifer from inner shelf sediments of the Bay of Bengal, of the southeast India, Journal of Environmental micropaleontology, microbiology, meiobenthology, 2, 60-67, 2005.

Reading, H. G.: Sedimentary Environments: Processes, Facies and Stratigraphy, 3rd Edn., Blackwell Publishing, Oxford, 1996.

Roozpeykar, A. and Maghfouri Moghaddam, I.: Benthic foraminifera as biostratigraphical and paleoecological indicators: An example from Oligo-Miocene deposits in the SW of Zagros basin, Iran, Geosience Frontiers, 30, 1-16, 2015.

Röttger, R. and Krüger, R.: Observations on the biology of Calcarinidae (Foraminiferida), Mar. Biol., 106, 419-425, 1990.

Saidova, K. M.: O znacheni bentosnych foraminifer v tolsche osadkov okhotskoga morja, Akademy Nauka SSSR, 93, 143-146, 1953.

Samir, A. M. and El-Din, A. B.: Benthic foraminiferal assemblages and morphological abnormalities as pollution proxies in two Egyptian bays, Mar. Micropaleontol., 41, 193-227, 2001.

Schiebel, R., Bijma, J., and Hemleben, C.: Population dynamics of the plantktic foraminifer Globigerina bulloides (d'Orbigny) from the eastern N. Atlantic, Deep-Sea Res., 44, 1-10, 1997.

Scott, D. B., Schafer, C. T., and Medioli, F.: Eastern Canadian estuarine foraminifera: a framework for comparison, J. Foramin. Res., 10, 205-234, 1980.

Schütz, K., Harzhauser, M., Rogl, F., Coric, S., and Galovic, I.: Foraminiferen und Phytoplanktonaus dem unteren Sarmatium des siidlichen Wiener Beckens (Petronell, Niederosterreich), Jahrubuch Der Geologichen Bundesansalt, 147, 449-488, 2007.

Seibold, I.: Benthonic Foraminifera from the Coast and Lagoon of Cochin (South India), Revista Espanola Micropaleontologica, 7, 175-213, 1975.

Seibold, I. and Seibold, E.: Offshore and lagoonal benthic foraminifera near Cochin (southwest India) - distribution, transport, ecological aspects, Neues Jahrbuch für Geologie und Päleontologie, 162, 1-56, 1981.

Seiglie, G. A.: Distribution of Foraminifers in the sediments of Araya-Los Testigos Shelf and Upper Slope, Caribb. J. Sci., 6, 93-118, 1966.

Seiglie, G. A.: Progress Report on the Study of the Foraminifers from off the Western Coast of Puerto Rico, Puerto Rico Nuclear Center Marine Biology Program, Progress Summary, 5, 107117, 1967.
Sen Gupta, B. K.: Modern foraminifera, Kluwer Academic Publishers, New York, 2003.

Suresh Gandhi, M., Solai, A., and Kalaivanan, R.: Distribution and ecology of engineering sciences and research of Adyar River, Chennai, Tamilnadu, India, International Journal of Engineering Sciences and Research Technology, 2, 2965-2977, 2013.

Szczechura, J.: Middle Miocene foraminiferal biochronology and ecology of SE Poland, Acta Paleontologica Polonica, 27, 3-44, 1982.

Szczechura, J.: Age and evolution of depositional enviroments of the supra - evaporitic deposits in the northern, marginal part of the Carpathian Foredeep: micropaleontological evidence, Geol. Q., 44, 81-100, 2000.

Thayer, C. V.: Morphologic adaptation of benthic invertebrates to soft substrata, J. Mar. Res., 33, 177-189, 1975.

Tóth, E., Görög, A., Lecuyer, V., Moissette, P., Balter, B., and Monostori, M.: Paleoenvironment reconstruction of the Sarmatian (Middle Miocene) centra Paratethys based on paleontological and geochemical analyses of foraminifera, ostracods, gastropods and rodents, Geol. Mag., 147, 299-314, 2010.

Tsuchiya, M., Tazume, M., and Kitazato, H.: Molecular characterization of the non-costate morphotypes of buliminid foraminifers based on internal transcribed region of ribosomal DNA (ITS rDNA) sequence data, Mar. Micropaleontol., 69, 212-224, 2008.

Tsuchiya, M., Grimm, G. W., Heinz, P., Stögerer, K., Ertan, K. T., Collen, J., Brüchert, V., Hemleben, C., Hemleben, V., and Kitazato, H.: Ribosomal DNA shows extremely low genetic divergence in a world-wide distributed, but disjunct and highly adapted marine protozoan (Virgulinella fragilis, Foraminiferida), Mar. Micropaleontol., 70, 8-19, 2009.

Williamson, W. C.: On the recent Foraminifera of Great Britain, Ray Society, London, 1-107, 1858.

Wright, R. C.: Miliolidae (Foraminfferos) recientes del estuario del Rio Quequen Grande, Revista del Museo Argentino de Ciencias Naturales, Hidrobiologia, 2, 225-256, 1968.

Yanko, V., Kronfeld, J., and Flexer, A.: Response of benthic foraminifera to various pollution sources: implications of pollution monitoring, J. Foramin. Res., 24, 1-17, 1994.

Yanko, V., Ahmad, M., and Kaminski, M.: Morphological deformities of benthic foraminiferal test in response to pollution by heavy metals: implications for pollution monitoring, J. Foramin. Res., 28, 177-200, 1998. 